\title{
Turning Internal Product Knowledge into External Service Offers: Building PSS Capabilities
}

\author{
J. Wallin ${ }^{12}$ \\ ${ }^{1}$ Innovation and Design, Business Administration Technology \& Social Sciences, Luleå University of \\ Technology, 97187 Luleå, Sweden \\ ${ }^{2}$ Quality PD, Volvo Aero Corporation, 46181 Trollhättan, Sweden \\ johanna.wallin@Itu.se \\ johanna.wallin@volvo.com
}

\begin{abstract}
The transition from product development towards development of product-service systems (PSS) challenges manufacturing industry today. This paper is based on a case study of a company in the aerospace industry that turned their internal product knowledge into an external service offer, which challenged established structures of the product development process. The process and challenges of the capitalization of internal knowledge were documented as well as the capabilities needed. This case emphasizes the importance of collaboration between different areas of expertise and it also shows that PSS development enhances the need for engineers who are skilled in more than one area.
\end{abstract}

Keywords:

Product-Service System, Technical Services, Innovation, Process, Capabilities, Case study

\section{INTRODUCTION}

\subsection{The PSS transition}

Manufacturing industries are undergoing a transition towards the integration of more and more services into their traditional product offers and provide product-service systems (PSS) [1] [2] which includes both tangible products and intangible services and requires that the product and service is developed simultaneously. Baines et al (2008) [1] found three factors that drive companies to PSS; financial (for a higher profit margin or more stable income), strategic (gaining competitive advantage) and marketing (use services to sell more product).

Technical services, such as maintenance, after-sale support and user training, enhance the customers satisfaction and experience beyond the core value of the products. These services are often developed and provided by a service organization. But the product development organization in the manufacturing industry is lacking in experience of developing services, although they hold an extensive technical knowledge of the product which is a good foundation in the innovation of new services to enhance the value to the customer.

One opportunity for manufacturing companies to expand its business is to capitalize on knowledge that traditionally has been used for internal purposes. "Sticking to what they know" has been an argument for firms not to go into services [3]. However, the same reason could be used to do so. The knowledge, skills and tools that are based on the company's history of developing and producing products could be the foundation in creating a service offer for external customers as well.

The differences between products and services have been noted in literature [4] [5] [6] [7]. These differences regard the time perspective (products are first produced and then used, whereas services are produced and used, at the same time), ownership (the ownership of a product is transferred to the customer when the product is sold; whereas the ownership of a service is not generally transferred) and material (products are tangible and services are intangible and unlike products, services cannot be stored) [4] [5] [6] [7]. However, Vandermerwe and Rada (1988) [3] point out that it is not valid for industries to assume they can do one without the other because they can draw simplistic distinctions between goods and services. But the difference between products and services could involve challenges for the development of PSS, since the innovation of a system is more complex and at a higher level of abstraction.

The transition towards PSS development involves new approches, new processes, new challenges and new capabilities that link service and business development with the product development capabilities.

This paper addresses some of the challenges for a manufacturing company that appears when developing PSS offers for external customers. The paper focuses on the following key questions: What internal process is employed for transferring product knowledge into service offer? What capabilities are needed to transfer product knowledge into service offer? How can the product development organization deal with the challenges related to process and capabilities development to ensure transfer of product knowledge into service offer?

This paper is based on a case in the aerospace industry, which is an industry that is characterized by its high technology content, long product life cycles, and established structures and processes. Each aircraft engine is an opportunity to supply a stream of spare parts at high margins. Therefore, the engines are usually sold at largely reduced prices and the engine developers instead make their profit from maintenance and the supply of spare part. However, commitment and availability is extendedly 
valued to the customer, compared to the sale and purchase of the traditional product. This has lead to offers such as for example TotalCare ${ }^{\circledR}$ by Rolls Royce [8], or 'Power by the hour' where airlines pay for the functionality of the engine and receives services in a package together with the product.

The company in this case study develops military aircraft engines, engines components on the commercial market, as well as maintenance services. The company has recently extended their internal product knowledge from developing aircraft engines into external service offers beyond the traditional maintenance services.

The focus of the paper is one PSS innovation project that has emerged from the product development organization, not the service organization. It is a bottom-up, technology push innovation.

There is an excessive amount of data available from flight operations, which have been collected in support of safety and customer support processes. The analysis of this data allows useful statistical information. The combination of this information with the understanding of engine behaviour in different operations yields knowledge of the consequences of the product deterioration.

With the use of the extensive data collected for decades, the knowledge of engine behaviour and the combination of methodologies, the company has developed what they call the Life Tracking System (LTS), a software system that has automated the calculation of the life consumption of the engine components based on actual flight information. The system involves a method, commonly used in one area, now applied in a completely new area where it has not been used before, connecting different areas of expertise.

The creation of software has enabled the services of more accurately calculation the life consumptions of the engine component which can reduce the use of spare parts and increase safety.

This research has been limited to the development and innovation of this PSS, but does not involve the delivery of the system to customer, since the company is currently in the middle of that process.

\section{METHODOLOGY}

This paper is based on semi-structured interviews with stakeholders of a PSS development project. The rational for selecting this particular project was that it stretched the established structures of product development processes and developed a PSS innovation that 2010 received the annual technology prize at the company. The interviewees have been involved within the project (such as project managers, engineers and consultants) or have had connections to the project in a supporting position (such as steering committee, functional manager or business development), and they could therefore give an insight to the development process, the challenges and success factors of this PSS innovation. The interviews were approximately one hour long, audio taped and transcribed.

\section{THEORETICAL FRAMEWORK}

The research presented in this paper addresses the challenges related to PSS process and capabilities.

\subsection{PSS processes}

The design of product-service systems involves requirements for both products and services, and these characteristics will also influence each other, which lead to challenges for the design team [6]. Designing services could be difficult for engineers who are used to product design, product development processes and mental models of product [9].
PSS development changes the relationships of the stakeholders involved in the development, as well as the development of process and methods. Several stakeholders may need to be involved, since the system consists of both products and services; the classical hardware is only one part of the solution and does therefore not necessarily need to meet all the requirements, which the service can meet. The product development experts need to work closely with the service development experts [2]. The designer need to be capable of dealing with all competences needed, and it also requires new competences for the designer since the scope of the system is larger [5] [10]. The designer need to focus more on the customer need phase and find solutions beyond the properties of the traditional product [10].

This may also require a fundamental shift in corporate culture, involve organizational changes [11], metrics, incentives and business models in the organization [12]. Considering these challenges it is not hard to understand that the transition towards PSS might meet resistance and involve conflicts between groups of people in the organization [13].

Isaksson et al (2011) [14] developed a framework for development of PSS, including a six-phase life cycle model, consisting of Need phase, Solution seeking, Solution development, Solution realization, Solution support and Solution closure.

\subsection{PSS Capabilities}

PSS innovation is related to different types of capabilities mentioned in literature.

Core Capability is the knowledge set that distinguishes and provides a competitive advantage for the firm and consists of the knowledge and skills that are embedded in the organization, the technical systems, the managerial system as well as values and norms [15]. However, Leonard-Barton (1992) [15] also claims that the core capabilities enables innovation but at the same time hinders it. Organizations must challenge their current paradigms to enable innovation. Lall (1992) [16] points out that as firm undertake more complex tasks the basic core must grow and draw selectively on others to complement its own capabilities.

Dynamic capability refers to the firm's ability to adapt, renew, reconfigure and re-create their resources in line with the competitive environment [17]. Rothaermel and Hess (2007) [18] show in their research that a firm's adaptation and innovation depends on its intellectual human capital and that the antecedents to dynamic capabilities lie across different levels: individual, firm and external network.

Innovation capability is the skills and knowledge needed to effectively absorb, master and improve existing technologies in order to create new ones [19] [16]. The innovation capabilities of a firm accumulate from internal inputs (such as professional backgrounds, skills and efforts to improve technology) and external inputs (such as intensity of networking, proximity advantages related to networking and receipt of institutional support) [19].

Kogut and Zander (1992) [20] introduces the concept of combinative capabilities as the intersection of the capability of the firm to exploit its knowledge and the unexplored potential of the technology.

However, there has been limited research on capabilities related to PSS development. But Brady et al (2005) [21] identified four new capabilities that firms need to develop as they shift towards providing integrated solutions: System integration capabilities, (to design and integrate systems of hardware, software and services) operational service capabilities (to maintain, operate, upgrade and 
renovate through the operational life cycle), business consulting capabilities (to provide customers with advice) and financing capabilities (to help customers purchase high-cost products and manage an installed base of capital assets). Brady et al (2005) [21] also identified new management skills needed for integrated systems regarding key account, risk, financial, legal, information, innovation and portfolio management.

\section{THE EARLY PHASES OF PSS DEVELOPMENT}

The project in this case study has formally followed the process for Information Systems development at the company, a process similar to the product development process.

The informal process of the PSS development of this case study is based on the framework presented by Isaksson et al (2011) [14], but does only involve the first three stages since the project in this case is at that stage of realizing the solution and actual provision of the PSS as this article is written.

\subsection{Need phase}

The need phase included the identification of the problem situation and customer needs.

Calculating the life of a component is crucial for the aerospace industry where safety is always primary. The calculation of life consumption is a service performed to the customer on the military market. However, the process of doing these calculations has been slow and not optimal. The engineers started thinking that: "There is got to be a better way". The vision to do this quickly and efficiently has driven the development, but also the value creation opportunities to the customer.

The close relationship with the military customer and the knowledge about their processes also revealed their needs for improvement, even though they were not formally expressed by the customer.

\subsection{Solution Seeking}

The solution seeking phase involved a pre-study on the problem situation indentified the risks but also the value creation opportunities. It showed the size of the problem and the economical and safety gains with a PSS development. Interest was gained from the customer for the potential new products and services.

The pre-study resulted in the creation of a demonstrator/prototype that showed the value of the system, "With the prototype we could show the value for the customer" expressed on interviewee. The demonstrator/prototype was an important milestone: "You must come to the position where you have something to show" and it initiated further development.

\subsection{Solution Development}

The solution development involved combination of different areas of expertise, software, hardware and services. The project team was grouped to develop different parts of the system. Working iteratively enabled good communication between the areas.

The solution development phase also involved business development. The customer could potentially decrease the amount of spare parts which is a big economical benefit. However, the selling of spare parts is a big part of the company profit. To sell a service that meant a decrease of product sale, therefore the creation of a new business models were necessary, not only to specifically show the value for the customer but also to find a new way to gain profit for the company.
This phase also involved identifying new potential customers for the PSS. However, the delivery to the first customer is important for the delivery to other customers.

\section{THE CHALLENGES OF PSS DEVELOPMENT}

The process of developing PSS has involved certain challenges for the team and the company. These challenges could also be part of the traditional product development at the company but has been particular evident in this PSS development.

\subsection{Customer knowledge and contact}

Understanding your customer so well so you know their needs, before they do themselves, is a good start in the innovation process, however easier said than done. One interviewee said: "The company could gain a lot by listening to the customer. Not think too much about what we have right now... We have our history and our knowledge. But if we listen to our customer we realize that we can do more than that."

\subsection{Risk of going into unknown grounds}

Even though the company has previously developed services such as maintenance and product support, the creation of software was an unknown area for the company which involved risks. And it was also hard to see the potential value in the new business opportunities.

\subsection{Communication between areas of expertise}

The company strength could also be part of its weakness. The company is specialized in certain competences, such as structural and aero/thermo dynamics. Each specialization creates a common language within the group, which is positive for the specialization, but the downfall is that it makes it harder for the understanding, spreading and combining of innovative ideas.

\subsection{Building up new knowledge}

In some areas the company had the competence that was needed. But going into a new area that included software development, the company needed to complement the internal competence with software competence, which was brought in through consultants.

However, even though consultants can bring in new expertise, it is not internal competence, which at the same time needs to be built up for future projects:"We must continue to produce, but we must grow in other ways too" expressed one interviewee.

\subsection{New business models}

Entering into new businesses of services means new business models. The company was a bit reluctant to the idea of selling a service that would decreased the amount of spare parts, which traditionally been an important source of revenue. New PSS business models needed to be created in order to ascertain value for both company and customer and perhaps even customers' customer.

There is a complexity in these kinds of offers that involve both new technology and new business models which complicates the selling of the system, "The value is there. No doubt about that. The question is how to sell it" expressed one interviewee.

\section{PSS INNOVATION CAPABILITIES}

The capabilities needed for this PSS development show how the company enabled the challenges of the development. The PSS capabilities are related to core capabilities, dynamic capabilities and innovation capabilities, which are also related to each other (Figure 1). 
This case study are related to the development and design of PSS rather than the operation and delivery of such system and are therefore related to what Brady et at (2005) [21] identified as system integration capabilities.

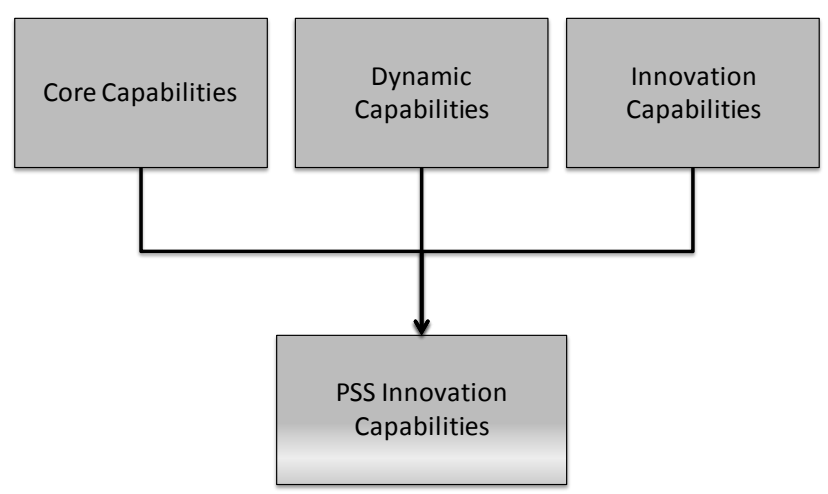

Figure 1: PSS Innovation Capabilities.

\subsection{Core Capabilities}

Core Capability is the knowledge set that distinguishes and provides a competitive advantage for the firm.

\section{Core Competence}

The company's core capabilities are related to the product development aircraft engines and include competences such as structural and aero/thermo dynamics, performance and engine systems. The core competence identified the problem situation the initiated this PSS project.

\section{Supporting system}

The company have technical systems for support, for example the project had access to a large Linux cluster, which was a necessity to handle large amount of data.

As the project proceeded more resources were needed, resources that were scarce at the company, since they were also needed in product development projects. But the dedication of certain people within the project convinced manager supported them in it.

\subsection{Dynamic capabilities}

Dynamic capability is the firm's ability to adapt, renew, reconfigure and re-create their resources in line with the competitive environment.

\section{New competence}

In the solution seeking phase consultants were brought in, primarily regarding software development. This meant that the company brought in excellence in areas where they were lacking in knowledge and experience.

Some consultants were employed by the company in order to keep and build up this new competence internally and support delivery of the system as well as supporting further development and similar projects. If all consultants would have left, the company would be left with the new information but without the knowledge of the system.

\section{Cross functionality}

Cross functionality can be noted on several levels in the company: organizational, team and individual level.

The company have changed from a function focused organization to a business focus, which made the functional areas to somewhat emerge. This is complemented by the cross functional project teams, which is essential to communicate and realize innovative ideas. Within the particular project of this case study cross functionality has been essential since it has involves several areas of expertise. The iterative way of working has enabled communication between the areas.

Key individuals within the project have also crossed the specialization areas, they have been able to see the whole picture and be a foundation in the communication between groups.

\section{Good relationship with the customer}

The company has developed close collaboration with their customers, and especially on the military market the company has great knowledge about the customer, their processes and their system. This relationship also means that the company understands their customer needs.

To enter into a new area of business involves risks, and therefore it is very valuable to have contact with the customer as early as possible in the development. In this case one customer was also part in financing the development.

\section{Supportive strategy for change}

The Group has a Soft Product strategy, "soft product" meaning products and services that enhance the customer experience and satisfaction beyond the core product. This strategy has encouraged these types of project which previously might have been regarded as "not part of the core business". But this strategy put more focus on PSS development and enabled the resources needed. Within the Group the company has come far in developing maintenance and product support services; with this project the company has taken one step further to customer oriented product-service system.

\subsection{Innovation Capabilities}

Innovation capability is the skills and knowledge needed to improve existing technologies and to create new ones.

\section{Passion for innovation}

Many interviewees stated the importance of individual's passion for innovation: "You need people who are passionate about what they do" said one interviewee, "If someone is passionate about something, let them keep on doing it, and we will see where it leads to" said another. In this case study there were key individuals who were so passionate for the idea of this PSS that their managers for this reason let them continue with the development even in the early times when the internal value was questioned.

\section{Innovative Climate}

Innovation needs time for creativity and development of ideas. The iterative way of working, the mix of personalities and the collaborative environment enabled solution seeking and development. It also contributed to keeping people longer on the team, which promotes continuity and getting creative people who are driven by what they do.

The customer's requirements have only regarded the delivery of the service, which has left creative space for the team to design the system.

\section{Innovation reward}

Every year the company gives a technology prize, to encourage innovation. Receiving this prize in the development phase, gave the project attention to the value of the new system.

\section{DISCUSSION AND CONCLUSION}

The internal process of successfully transferring product knowledge into service offer was recognized within the product development organization. The early phases of PSS development includes three stages, Need phase (where the internal problem and customer needs are identified), Solution seeking (where the size of the problem 
was understood and a demonstrator was created) and Solution development (where the PSS was developed and the business model created). The PSS development has differed from the product development processes since it has involved new business development and certain challenges has been more evident compared to traditional product development at the company. The different stages of the process have involved different challenges, and these challenges have been supported by different capabilities that show how the company has dealt with the issues (Table 1).

\begin{tabular}{|c|c|c|c|}
\hline $\begin{array}{l}\text { PROCESS } \\
\text { STAGES }\end{array}$ & KEY ACTIVITIES & CHALLENGES & $\begin{array}{l}\text { SUPPORTIVE } \\
\text { CAPABILITIES }\end{array}$ \\
\hline Need phase & $\begin{array}{l}\text { Identification of internal } \\
\text { problem situation } \\
\text { Identification of customer } \\
\text { needs }\end{array}$ & $\begin{array}{l}\text { Customer knowledge and } \\
\text { contact }\end{array}$ & $\begin{array}{l}\text { Core Capabilities: } \\
\text { Core competence } \\
\text { Dynamic Capabilities: } \\
\text { Good relationship with } \\
\text { the customer } \\
\text { Innovation Capabilities: } \\
\text { Passion for innovation }\end{array}$ \\
\hline Solution seeking & $\begin{array}{l}\text { Understanding the size of the } \\
\text { problem situation. } \\
\text { Gain interest from customers } \\
\text { Creation of a demonstrator }\end{array}$ & $\begin{array}{l}\text { Customer knowledge and } \\
\text { contact } \\
\text { Risks of going into } \\
\text { unknown grounds } \\
\text { Communication between } \\
\text { areas of expertise } \\
\text { Building up new } \\
\text { knowledge }\end{array}$ & $\begin{array}{l}\text { Core Capabilities: } \\
\text { Core competence } \\
\text { Supportive system } \\
\text { Dynamic Capabilities: } \\
\text { New competence } \\
\text { Cross functionality } \\
\text { Good relationship with } \\
\text { the customer } \\
\text { Innovation Capabilities: } \\
\text { Passion for innovation } \\
\text { Innovative Climate }\end{array}$ \\
\hline $\begin{array}{c}\text { Solution } \\
\text { Development }\end{array}$ & $\begin{array}{l}\text { Development of PSS through } \\
\text { the combination of different } \\
\text { areas of expertise } \\
\text { Create a business model that } \\
\text { creates value for both } \\
\text { company and customer (and } \\
\text { customer's customer in some } \\
\text { cases) }\end{array}$ & $\begin{array}{l}\text { Customer knowledge and } \\
\text { contact } \\
\text { Communication between } \\
\text { areas of expertise } \\
\text { Building up new } \\
\text { knowledge } \\
\text { New business models }\end{array}$ & $\begin{array}{l}\text { Core Capabilities: } \\
\text { Core competence } \\
\text { Supporting system } \\
\text { Dynamic Capabilities: } \\
\text { New competences } \\
\text { Cross functionality } \\
\text { Good relationship with } \\
\text { the customer } \\
\text { Supportive Strategy } \\
\text { Innovation Capabilities: } \\
\text { Passion for innovation } \\
\text { Innovative Climate } \\
\text { Innovation reward }\end{array}$ \\
\hline
\end{tabular}

Table 1: Connection between process stages, challenges and capabilities.

This case study contributes to the understanding of how firms build capabilities needed for PSS development. PSS capabilities refer to the skills and knowledge needed to effectively develop both products and services to create value for the existing or new customers. These capabilities are related to core capabilities, dynamic capabilities and innovation capabilities.

The core capabilities have been core competence related to product development and the supportive system. The company has used their product knowledge to create new service offers with the help from the supportive system.

The transfer from product development to PSS development requires an ability to change and adapt. The dynamic capabilities have been the buildup of new competence, the cross functionality of competences on several levels, the good relationship with customers to identify needs and create value, and the supportive strategy for change to encourage PSS development.
The Innovation capabilities that have enabled the development of a PSS innovation have been the individuals' passion for innovation, the innovative climate to enable innovation development and innovation rewards to pay attention to the value creation.

Research has emphasized the external networks as dynamic capabilities. This case rather emphasize the internal network, it shows that the collaboration between the individuals and their teams has enabled the PSS development. It also shows that PSS development enhances the need for engineers who are skilled in more than one area.

Although one project does not alter the whole organization it does pave the way for further organizational transition towards PSS development. This project has resulted in the identification of new business opportunities for the company and the foundation of new capabilities. These capabilities need to be packaged appropriately and increased in order to effectively turn 
internal product knowledge into external service offers. However, the findings show that when a company is new to these kinds of service offers, emphasis has been put on the capabilities of key individual, such as their cross functionality and passion for innovation. These individual capabilities need to be transferred into organizational capabilities to secure future success in PSS development.

\section{ACKNOWLEDGMENTS}

The author is grateful for the time and participation from interviewees, colleagues and supervisors. Financial support from Vinnova through NFFP, PIEp and Volvo is also greatly acknowledged.

\section{REFERENCES}

[1] Baines T.S., Lightfoot, H.W., Benedettini, O. and Kay, J.M (2009). The servitization of manufacturing - A review of literature and reflection on future challenges. Journal of Manufacturing Technology Management, Vol. 20 No. 5, pp. 547-567.

[2] Tukker, A. and Tischner, U. (Ed) (2006). New Business for Old Europe: Product-Service Development, Competitiveness and Sustainability. Greenleaf Publishing Ltd. Great Britain.

[3] Vandermerwe, S. and Rada, J. (1988). Servitization of Business: Adding Value by Adding Services. European Management Journal, Vol. 6 No. 4, pp. 314-324.

[4] Morelli, N. (2002). Designing Product/Service Systems: A Methodological Exploration. Design Issues, Vol. 18 No. 3 Summer 2002, pp. 3-17.

[5] Morelli, N. (2003). Product-service systems, a perspective shift for designers: A case study: the design of telecentre. Design Studies 24, pp. 73-99.

[6] Brezet, J.C., Bijma, A.S., Ehrenfeld, J. and Silvester, S. (2001). The Design of Eco-Efficient Services Method, tools and review of the case study based 'Designing Eco-efficient Service' project. Design for Sustainability Program, Delft University of Technology, June.

[7] Aurich, J.C, Fuchs, C., and Wagenknechy, C (2006). Life cycle oriented design of technical Product-Service Systems. Journal of Cleaner Production, 14, pp. 1480-1494.

[8] Harrison, A. (2006). Design for service Harmonising product design with a services strategy, Proceedings of the ASME Turbo Expo 2006, Vol 2, Barcelona, Spain, May 06-11, pp. 135143.

[9] Uchihira, N., Kyoya, Y., Kim, S K., Maeda, K., Ozawa, M. and Ishii, K. (2008). Analysis and Design Methodology for Product-Based Services. 21st Annual Conference of The Japanese Society for
Artificial Intelligence, JSAI 2007, LNAI 4914, pp. 1325, 2008.

[10] Isaksson, O., Larsson, T. and Öhrwall Rönnbäck, A. (2009). Development of product-service systems: challenges and opportunities for the manufacturing firm, Journal of Engineering Design, Vol. 20, No. 4 , August 2009, pp. 329-348.

[11] Mont, O.K. (2002). Clarifying the concept of product-service system. Journal of Cleaner Production 10, pp. 237-245.

[12] Oliva, R. and Kallenberg, R. (2003). Managing the transition from products to services. International Journal of Service Industry Management, Vol. 14, No. 2, pp. 160-172.

[13] Mathieu, V. (2001). Service strategies within the manufacturing sector: benefits, costs and partnership. International Journal of Service Industry Management, Vol. 12 No. 5, pp. 451-475.

[14] Isaksson, O., Larsson, T. And Johansson, P. (2011). Towards a Framework for developing Product/Service Systems. Proceedings of the $3^{\text {Ta }}$ CIRP International Conference on Industrial Product Service Systems, Braunschweig, Germany, pp. 4449.

[15] Leonard-Barton, D. (1992). Core Capabilities and Core Rigidities: A Paradox in Managing New Product Development. Strategic Management Journal, Vol. 13, pp. 111-125.

[16] Lall, S. (1992). Technological Capabilities and Industrialization. World Development, Vol. 20, No. 2, pp. 165-186.

[17] Wang, C. And Ahmed, P (2007). Dynamic capabilities: A review and research agenda. International Journal of Management Reviews, Vol. 9 Iss. 1, pp. 31-51.

[18] Rothaermel, F. And Hess, A. (2007). Building Dynamic Capabilities: Innovation Driven by Individual-, Firm-, and Network-Level Effects. Organization Science, Vol. 18, No. 6, pp. 898-921.

[19] Romijn, H. and Albaladejo, M. (2002). Determinants of innovation capability in small electronics and software firms in southeast England. Research Policy, 31, pp. 1053-1067.

[20] Kogut, B. and Zander, U. (1992). Knowledge of the firm, combinative Capabilities, and the replication of Technology. Organization Science, Vol. 3, No. 3, pp. 383-397.

[21] Brady, T., Davies, A. and Gann, D.M. (2005). Creating value by delivering integrated solutions. International Journal of Project Management, 23 , pp. 360-365. 